\title{
Perspectives in isolation of microRNA from thyroid fine-needle aspiration: reply to the letter "Nucleic acid recovery from thyroid fine-needle cytology slides"
}

\author{
Perspectivas no isolamento de microRNA de punção aspirativa por \\ agulha fina de tiroide: resposta à carta "Ácidos nucleicos extraídos \\ de lâminas com citologia de punção de agulha fina de tiroide"
}

${ }^{1}$ Laboratory of Molecular and Translational Endocrinology, Department of Medicine, Escola Paulista de Medicina, Universidade Federal de São Paulo (Unifesp/ EPM), São Paulo, SP, Brazil ${ }^{2}$ Laboratory of Molecular and Translational Endocrinology, Department of Biochemistry, Unifesp/EPM, São Paulo, SP, Brazil

* All authors contributed equally to this study

Correspondence to: Magnus R. Dias da Silva Laboratório de Endocrinologia Molecular e Translacional, Universidade Federal de São Paulo Rua Pedro de Toledo, $669,11^{\circ}$ andar 04039-032 - São Paulo, SP, Brazil mrdsilva@unifesp.br

Received on May/9/2013 Accepted on Jun/6/2013
Marina M. L. Kizys ${ }^{1 *}$, Mirian G. Cardoso ${ }^{1,2^{*}}$, Susan C. Lindsey', Maria Clara C. Melo', Magnus R. Dias-da-Silva' ${ }^{1,2}$

$\mathrm{E}$ fforts have been made to improve the isolation of nucleic acids from long-term preserved samples $(1,2)$. This is a challenge when dealing with formalin-fixed/ paraffin-embedded (FFPE) tissues and fine needle aspiration (FNA) samples from stained slides. In our recent study (3) using in-house protocols, we optimized the methods used for nucleic acid extraction, including co-extraction of RNA/DNA from thyroid FNA in stained slides samples and FFPE thyroid tissues by means of modifications of the standard TRIzol ${ }^{\circledR}$ reagent (Life Technologies, Carlsbad, CA, USA) protocol, making genetic and epigenetic studies possible using the same sample. In addition, the recovery of nucleic acid from the same thyroid FNA stained slides that had been previously analyzed by a cytopathologist enables an integrated diagnosis, as well as repeated FNAs, reducing the costs with cytopathology and molecular procedures.

Several studies have been published regarding the potential of microRNA (miR$\mathrm{NA})$ as a molecular biomarker of thyroid cancer (5). miRNA are smaller ( 19-22 bp) and more stable than messenger RNA (mRNA), so its detection and recovery are equally feasible, as objectively demonstrated by Saito and cols. In this context, we are honored to know that our article has stimulated Professor Kimura's team to show their results in miRNA extraction from thyroid FNA stained slides. They were successful with the isolation of RNA and analysis of several miRNAs. Besides, our group and Kimura's team were able to co-extract DNA/RNA with further $B R A F$ analysis by means of PCR-Sequencing (3) and PCR-RFLP analysis (Saito and cols.).

In conclusion, miRNA isolation from thyroid FNA stained slides is another promising tool when investigating thyroid nodules, especially those with uncertain cytopathology results.

Acknowledgements: this study was financially supported by São Paulo Research Foundation (Fapesp) 2012/01628-0 (MMLK), 2012/02465-8 (MGC), 2009/50575-4 (SCL), 2006/60402-1 (MRDS), and 2011/20747-8 (MRDS).

Disclosure: no potential conflict of interest relevant to this article was reported. 


\section{REFERENCES}

1. Pandit P, Cooper-White J, Punyadeera C. High-yield RNA-extraction method for saliva. Clin Chem. 2013. Epub 2013/04/09.

2. Ferraz C, Rehfeld C, Krogdahl A, Precht Jensen EM, Bosenberg $E$, Narz F, et al. Detection of PAX8/PPARG and RET/PTC rearrangements is feasible in routine air-dried fine needle aspiration smears. Thyroid. 2012;22(10):1025-30.

3. Kizys MM, Cardoso MG, Lindsey SC, Harada MY, Soares FA, Melo $\mathrm{MC}$, et al. Optimizing nucleic acid extraction from thyroid fine- needle aspiration cells in stained slides, formalin-fixed/paraffinembedded tissues, and long-term stored blood samples. Arq Bras Endocrinol Metab. 2012;56(9):618-26.

4. Kitano M, Rahbari R, Patterson EE, Steinberg SM, Prasad NB, Wang $Y$, et al. Evaluation of candidate diagnostic microRNAs in thyroid fine-needle aspiration biopsy samples. Thyroid. 2012;22(3):285-91.

5. Lodewijk L, Prins AM, Kist JW, Valk GD, Kranenburg O, Rinkes IH, et al. The value of miRNA in diagnosing thyroid cancer: a systematic review. Cancer Biomark. 2012;11(6):229-38. Epub 12/19/2012. 